\title{
Extent of Parental School Involvement on Pupils' Academic Performance in Anambra State, Nigeria
}

\author{
J.O. Enemuo ${ }^{1}$, C.Y. Onyenwe ${ }^{2}$ \\ ${ }^{1,2}$ Department of Early Childhood and Primary Education, Nnamdi Azikiwe University, Anambra State, Nigeria \\ samuelbassey15@yahoo.com
}

\section{Abstract}

This study was carried out to investigate the extent of parentalschool involvement on pupils' academic performance in Anambra State. Four research questions and four null hypotheses guided the study. It adopted a descriptive survey research design. Two research questions guided the study. The population of the study consisted of 10,369 primary school teachers and 65,406 parents in Anambra state. The sample size for the study comprised of 736 which made up of 172 primary school teachers and 564 parents whose children/wards are in primary schools in Awka North, Awka south, Anambra, Dunukofia and Njikoka local Government Education Authorities were selected using multi-stage sampling. Data were collected using two structured questionnaires titled "Teachers Response on Parental School Involvement Questionnaire (TRPSIQ) and parent's response on school involvement questionnaire (PRSIQ). The TRPSIQ and PRSIQ was validated by three experts. The reliability of the instrument was determined using Cronbach Alpha which yielded an overall coefficient of 0.83. mean was used to answer the research questions while standard deviation was used to check the closeness of the respondent's response to the mean. The findings revealed that teachers and parents rated to a great extent parental involvement in child home-school communication and school volunteering for improvement in pupil's academic performance. Based on the findings, the researcher recommended among others that schools should create good communication language style that will foster close interaction between the parents and the child as well as the parents and the schools.

\section{Keywords}

parental involvement;

academic performance;

parental school

involvement; pupils

\section{Introduction}

The training and development of a child is naturally in the hands of the parents because they are central figures in their child's socialization and education (both formal and informal) to become responsible and productive members of the society. This is congruent with common assertion of sociologists that education can be an instrument of cultural change whose foundations begins from home (Uchendu, 2007). More importantly, the interactions between parents and their children are the most common connections held during a child's early years before entering primary school. The international standard classification of Education considers primary education as a single phase where programmes are typically designed to provide fundamental skills in reading, writing and mathematics and to establish a solid foundation for learning (Campbell, 2005).

Performance involves level of competency, proficiency, knowledge and skills acquire. It is accomplishing whatever goals one sets for oneself which is done what one wants to do within the limits of the law, overcoming obstacles and attaining a high standard (Kilonz, 2017). Performance requires drive, ingle mindedness and it is about completing goals one has 
set for oneself. Similarly, Stringer and Heath (2008) noted the academic performance is the state or level of person's skill, the range, depth of his knowledge and his proficiency in a designed area of learning and behavior. Academic performance is the outcome of education, the extent to which pupil's teachers, or institutions have attained their educational goals. It is commonly measured by examinations or continuous assessment (Bossaert, et al, 2011).

Parental school involvement, like many other variables such as the pupils, teacher and school variables, are important determinants of pupils' academic performance. Dimbisso (2009) defined academic performance as what a learner is able to accomplish by execution of class work in school. Academic performance shows the effectiveness of a program in terms of pupils' outputs and in terms of understanding in the acquisition of knowledge and skills. Academic performance of pupils cannot be separated from their family situation and the degree of family connectedness.

Parent involvement in children's education has become an important factor for building these parent-child relationships and improving children's path to educational success. The two most influential settings in which children learn and develop occur at home with their parents and also at school with their teachers. Jaiswal (2017) believed that the home and school create overlapping spheres on children's development and academic performance and the collaboration between these two spheres can greatly influence the educational outcome of the children.

According to Epstein model, parental school involvement is outlined into different indices; communicating, volunteering, home-learning and decision-making. Communicating is an effective form of school-to-home and home-to-school communications about school programs and children's progress in school (Bower et al, 2011). Volunteering means creating ways for families to be engaged in school, it increases parental involvement by which parents feel welcomed and making sure they know that their support and assistance is needed and greatly appreciated. Decision-making therefore is a process that includes the parents, teachers, administrators and community members in making decisions about how a school operates (Callison, 2004).

\subsection{The Problem}

The persistent poor academic performance in Anambra State has raised serious concern among educational researchers, policy makers, and school personnel. Following this, parental school involvement has been consistently identified as one major variable with important potential for improving the school performance of all pupils.

At present, it could be observed that some parents are deeply committed and are involved in the school activities of their child's school activities. However, some other parents who are willing to be involved lack methods of collaborating with the school in order to raise their children's chances of academic success. If parents show no interest or evidence of personal involvement in their children's education, they will not be serious and may not be motivated to work harder to achieve good academic success.

\subsection{Purpose of the Study}

The main purpose of this study was to ascertain the extent of parental school involvement in pupils' academic performance in Anambra State. In specific terms, the study determined the extent of;

1. Parental involvement in child's home-school communication for pupils' academic performance. 
2. Parental involvement in school volunteering in school volunteering for pupils' academic performance.

3. Parental involvement in child's home learning for pupils' academic performance.

\subsection{Research Questions}

1. What is the extent of parental involvement in child's home-school communication on pupil's academic performance?

2. What is the extent of parental involvement in school in school volunteering on pupil's academic performance?

\subsection{Hypothesis} significant

The following hypothesis, which guided the study, were tested at 0.05 level of

1. There is no significant difference in the mean responses of primary school teachers and parents on the extent of parental involvement in child's home school communication on pupil's academic performance

2. There is no significant difference in the mean responses of primary school teachers and parents on the extent of parental involvement in school volunteering on pupil's academic performance.

\section{Research Method}

This is study adopted descriptive survey designing determining the extent of parental school involvement on pupil's academic performance in Anambra state. 172 primary school teachers and 564 parents were sampled using the multi stage sampling technics.

Simple random sampling was used to draw out one out of five education zones in the state. The instrument used for the study were two questionnaires. The instruments were developed for teachers and parents.

The instrument for the study was a questionnaire titled "Parental school involvement questionnaire (PSIQ) on (Teachers' response) and Parental school involvement questionnaire (PSIQ) on Parents' response).

The sample size of the study is 172 primary school teachers and parents using multistage sampling technique. The instrument for data collection was two structured questionnaire which was validated by three experts. The inputs, corrections and comments by the experts guided the researcher in modifying the final copy of the instrument. Cronbach Alpha of 0.83 was obtained from the entire instrument.

The copies of the questionnaire were administered personally by the researcher and three research assistants who were briefed about the modalities for the administration and collection of the questionnaire. A period of four weeks was used for the distribution and collection of the instrument. A Total number of 736 copies were correctly filled and were used for data analysis.

Data collected in the study were analyzed using mean to answer the research questions. The item by item analysis was interpreted in relation to the real limits of the value assigned to categories of the instrument as follows: Very Great Extent $=3.50-4.00$, Great Extent $=2.50$ 3.49, Low Extent=1.50-2.49, Very Low Extent=0.50-1.49. The standard deviation was used to answer how far or close the respondents were from the mean. 


\begin{tabular}{|c|c|c|c|c|c|c|c|}
\hline & & \multicolumn{3}{|c|}{ Teachers } & \multicolumn{3}{|c|}{ Parents } \\
\hline $\mathbf{S} / \mathbf{N}$ & To what extent parents: & $\overline{\mathbf{X}}$ & SD & Remarks & $\overline{\mathbf{X}}$ & SD & Remarks \\
\hline 1 & $\begin{array}{l}\text { Are informed about school } \\
\text { activities on time e.g., PTA } \\
\text { meetings, annual inter-house } \\
\text { sport competition etc. }\end{array}$ & 2.88 & 1.13 & $\begin{array}{l}\text { Great } \\
\text { extent }\end{array}$ & 2.91 & 1.18 & $\begin{array}{l}\text { Great } \\
\text { extent }\end{array}$ \\
\hline 2 & $\begin{array}{l}\text { Talk to teacher as a class } \\
\text { teacher about their wards } \\
\text { accomplishment }\end{array}$ & 2.61 & 1.02 & $\begin{array}{l}\text { Great } \\
\text { extent }\end{array}$ & 2.87 & 1.12 & $\begin{array}{l}\text { Great } \\
\text { extent }\end{array}$ \\
\hline 3 & $\begin{array}{l}\text { Are informed of the academic } \\
\text { needs of their wards }\end{array}$ & 2.62 & 0.89 & $\begin{array}{l}\text { Great } \\
\text { extent }\end{array}$ & 2.61 & 1.02 & $\begin{array}{l}\text { Great } \\
\text { extent }\end{array}$ \\
\hline 4 & $\begin{array}{l}\text { Talk to teacher as a class } \\
\text { teacher about preparing their } \\
\text { wards for life after school }\end{array}$ & 1.59 & 1.23 & $\begin{array}{l}\text { Low } \\
\text { extent }\end{array}$ & 1.58 & 1.28 & $\begin{array}{l}\text { Low } \\
\text { extent }\end{array}$ \\
\hline 5 & $\begin{array}{l}\text { Talk to teacher about their } \\
\text { personal matters as it affects } \\
\text { their wards at school }\end{array}$ & 2.62 & 0.98 & $\begin{array}{l}\text { Great } \\
\text { extent }\end{array}$ & 2.59 & 0.89 & $\begin{array}{l}\text { Great } \\
\text { extent }\end{array}$ \\
\hline 6 & $\begin{array}{l}\text { Are provided with resourceful } \\
\text { information } \\
\text { to help them understand } \\
\text { how children learn better }\end{array}$ & 2.51 & 0.95 & $\begin{array}{l}\text { Great } \\
\text { extent }\end{array}$ & 2.62 & 0.97 & $\begin{array}{l}\text { Great } \\
\text { extent }\end{array}$ \\
\hline 7 & $\begin{array}{lr}\text { Are given feedback on } \\
\text { their children's } \\
\text { (report cards) }\end{array}$ & 3.68 & 0.59 & $\begin{array}{l}\text { Very Great } \\
\text { extent }\end{array}$ & 3.51 & 0.64 & $\begin{array}{l}\text { Very } \\
\text { great } \\
\text { extent }\end{array}$ \\
\hline 8 & $\begin{array}{l}\text { Talk to teacher about } \\
\text { disciplinary procedures }\end{array}$ & 2.41 & 1.01 & $\begin{array}{l}\text { Low } \\
\text { extent }\end{array}$ & 2.68 & 0.89 & $\begin{array}{l}\text { Great } \\
\text { extent }\end{array}$ \\
\hline 9 & $\begin{array}{l}\text { Give reports on their } \\
\text { children's deviant behavior }\end{array}$ & 2.63 & 0.98 & $\begin{array}{l}\text { Great } \\
\text { extent }\end{array}$ & 2.50 & 1.01 & $\begin{array}{l}\text { Great } \\
\text { extent }\end{array}$ \\
\hline 10 & $\begin{array}{l}\text { Attend PTA meetings to talk } \\
\text { about their wards learning and } \\
\text { behavior }\end{array}$ & 2.39 & 0.95 & $\begin{array}{l}\text { Low } \\
\text { extent }\end{array}$ & 2.62 & 0.98 & $\begin{array}{l}\text { Great } \\
\text { extent }\end{array}$ \\
\hline 11 & $\begin{array}{l}\text { Provided with information on } \\
\text { how to assist their child with } \\
\text { skills they need to improve }\end{array}$ & 2.44 & 1.04 & $\begin{array}{l}\text { Low } \\
\text { extent }\end{array}$ & 2.38 & 0.94 & $\begin{array}{l}\text { Low } \\
\text { extent }\end{array}$ \\
\hline & Cluster Mean & 2.58 & & $\begin{array}{l}\text { Great } \\
\text { extent }\end{array}$ & 2.62 & & $\begin{array}{l}\text { Great } \\
\text { extent }\end{array}$ \\
\hline
\end{tabular}

The table shows that teachers and parents indicate that parents are involved in child's home-school communication to a great extent. Data analysis of teachers indicated that parents to a low extent talk to teacher about disciplinary procedures; attend PTA meetings to talk about their wards learning and behavior. More so, Data analysis of parents indicate to a low extent that they talk to their wards' teachers about preparing their wards for life after school; they are provided with information on how to assist their child with skills they need to improve. This means that teachers and parents disagreed on their ratings on items 8 and 10 while they agreed on their ratings on the remaining items. The cluster means of 2.58 and 2.62 of teachers and parents respectively indicated that parental involvement in child's homeschool communication on pupils' academic performance is on a great extent. The standard 
deviation scores of both teachers $(0.59-1.13)$ and parents $(0.64-1.28)$ indicate that the difference between the standard deviation scores were not much, therefore this shows that the items are homogeneous.

\begin{tabular}{|c|c|c|c|c|c|c|}
\hline & \multicolumn{3}{|c|}{ Teachers } & \multicolumn{3}{|c|}{ Parents } \\
\hline To what extent do parents: & $\mathbf{X}$ & SD & Remarks & $\mathbf{X}$ & SD & Remarks \\
\hline $\begin{array}{l}\text { Participate in recruiting part-time } \\
\text { teachers to handle subjects }\end{array}$ & 2.18 & 1.05 & $\begin{array}{l}\text { Low } \\
\text { extent }\end{array}$ & 2.42 & 1.03 & $\begin{array}{l}\text { Low } \\
\text { extent }\end{array}$ \\
\hline $\begin{array}{l}\text { Work in the school as aide, } \\
\text { parent tutor, parent volunteer or } \\
\text { assistant teacher }\end{array}$ & 2.50 & .87 & $\begin{array}{l}\text { Great } \\
\text { extent }\end{array}$ & 2.49 & 1.05 & $\begin{array}{l}\text { Low } \\
\text { extent }\end{array}$ \\
\hline $\begin{array}{l}\text { Participate in fundraising activities at } \\
\text { school }\end{array}$ & 2.43 & .15 & $\begin{array}{l}\text { Great } \\
\text { extent }\end{array}$ & 1.41 & 2.88 & $\begin{array}{l}\text { Low } \\
\text { extent }\end{array}$ \\
\hline Volunteer to give prizes to best pupils & 2.52 & .92 & $\begin{array}{l}\text { Great } \\
\text { extent }\end{array}$ & 2.59 & 2.14 & $\begin{array}{l}\text { Great } \\
\text { extent }\end{array}$ \\
\hline $\begin{array}{l}\text { Volunteer to participate in extra- } \\
\text { curricular activities (such as, sports } \\
\text { day, school end of the year party) }\end{array}$ & 2.56 & .01 & $\begin{array}{l}\text { Great } \\
\text { extent }\end{array}$ & 2.52 & 2.92 & $\begin{array}{l}\text { Great } \\
\text { extent }\end{array}$ \\
\hline $\begin{array}{l}\text { Volunteer to take children to places of } \\
\text { educational interest (e.g. museums, } \\
\text { libraries, art galleries) }\end{array}$ & 2.47 & 0.96 & $\begin{array}{l}\text { Low } \\
\text { extent }\end{array}$ & 1.41 & 0.95 & $\begin{array}{l}\text { Low } \\
\text { extent }\end{array}$ \\
\hline $\begin{array}{l}\text { Volunteer to sensitize fellow } \\
\text { parents on developing home routines, } \\
\text { conditions and environments that } \\
\text { support their child's learning during } \\
\text { PTA meetings }\end{array}$ & 2.54 & 1.01 & $\begin{array}{l}\text { Great } \\
\text { Extent }\end{array}$ & 2.79 & 0.71 & $\begin{array}{l}\text { Great } \\
\text { extent }\end{array}$ \\
\hline $\begin{array}{l}\text { Are willing to support excursion } \\
\text { exercise of their children's school }\end{array}$ & 2.45 & 0.98 & $\begin{array}{l}\text { Low } \\
\text { extent }\end{array}$ & 2.46 & 0.95 & $\begin{array}{l}\text { Low } \\
\text { extent }\end{array}$ \\
\hline $\begin{array}{l}\text { Arrange conferences with their child's } \\
\text { teacher about reading progress }\end{array}$ & 2.18 & 0.88 & $\begin{array}{l}\text { Low } \\
\text { extent }\end{array}$ & 2.34 & 1.02 & $\begin{array}{l}\text { Low } \\
\text { extent }\end{array}$ \\
\hline Cluster Mean & 2.43 & & $\begin{array}{l}\text { Great } \\
\text { extent }\end{array}$ & 2.49 & & $\begin{array}{l}\text { Great } \\
\text { extent }\end{array}$ \\
\hline
\end{tabular}

The table shows that teachers and parents indicate that parents are involved in school volunteering to a great extent. Data analysis revealed that teachers indicated that parents to a low extent participate in recruiting part-time teachers to handle subjects; volunteer to take children to places of educational interest; are willing to support excursion exercise of their children's school; and arrange conferences with their child's teacher about reading progress. Similarly, data analysis revealed that parents to a low extent participate in recruiting part-time teachers to handle subjects; work in the school as aide, parent tutor or assistant teacher; volunteer to take children to places of educational interest; willing to support excursion exercise of their children's school; and arrange conferences with their child's teacher about reading progress. This means that teachers and parents disagreed in their ratings on items 13 and 14 while they agreed on their ratings on the remaining items. The cluster means of 2.43 and 2.49 indicate that parental involvement in school volunteering is on a great extent. The standard deviation scores of teachers $(0.87-1.15)$ and parents $(0.71-1.14)$ indicates that 
indicates that the difference between the standard deviation scores were not much, therefore this shows that the items are homogeneous.

Information was gotten from both parents and teachers on the extent of parents' school involvement in Anambra state. Three experts validated the instrument, two from department of early childhood and primary education and one from measurement and evaluation department, both in the faculty of education, Nnamdi Azikiwe university, Awka. Cronbach alpha procedure was used to determine the reliability of the instrument, which was 0.83 . the instrument was a 4-piont rating scale ranging from 1-4, 1 being the lowest while 5 is the highest as the response mode. The researcher administered the instrument to the sampled parents and teachers out of 740 copies of questionnaire, administered, 736 copies were completed and returned. Therefore, data analysis was based on the 736 duly completed and returned copies of the instrument. After collecting and collating the scores, means (x) were use in answering the research questions. The analysis of t-test was used in testing the null hypotheses at 0.05 level of significance. In testing the hypotheses, when the $p-=$ value is less than or equal to $0.05(p \leq 0.05)$ was rejected but if $p$-value was greater than 0.05 , the null hypotheses was accepted.

\section{Discussion}

The first research question focused on parental involvement in child's home-school communication on pupil's academic performance. The responses form both parents and teachers as show in table above.

The findings above issue revealed that teachers and parents opined that parental involvement in child's home school communication on performance was on a great extent.

The second findings revealed that parents and teachers opined that parental involvement in school volunteering on pupil's academic performance was on a greater extent.

The following implications were made: the results imply that although parents' involvement is show to be important it is also crucial to look at other factors such as private sector involvement in primary schools. From the findings revealed on parents do not take part in the preparation of school budget as well as finds it difficult to make suggestions about how to help their children learn. This imply that there should be more room to allow parents to participate in governance activities, developing parent outreach programs, planning support for parents whose children who have special needs etc. all these will foster cordial parentschool relationship thereby opening up to their child's teachers on how to help their children learn.

\section{Conclusion}

The study concluded that teachers and parents rated to a great extent parental involvement in; child's home-school communication; child's home learning for improved pupils' performance. Also, there was a significant difference in the mean responses of primary school teachers and parents on the extent of parental involvement in; child's homeschool communication and child's home learning for improved pupil's performance.

Based on the findings of this study, the following recommendations were made:

1. Parents and guardians should create a good communication language style that will foster close interaction between the parents and the child as well as the parents and the school. 
2. Parents and guardian should be aware of the learning environment of their children. Education authorities should, in collaboration with parents to encourage them to become part of not only children's learning but participate greatly.

3. Schools in Anambra State should increase communication opportunities between school and home through introducing various opportunities and modalities that are imperative for involving all parents and care givers in the schooling process of their children

\section{References}

Bossaert, G., Doumen, S., Buyse, E. \& Verschueren, K. (2011). Predicting children's academic achievement after the transition to first grade: A two-year longitudinal study.

Bower, H. A., Carolina, N., E-mail, C. H., \& Griffin, D. (2011). Can the Epstein Model of Elementary School? A Case Study. Professional School Counseling, 15(2), 77-88.

Callison, W. L. (2004) Raising test scores using parent involvement. Lanham, Maryland: ScareCrow Education.

Campbell, R. (2005). Primary education or primary schooling? International Journal of Phytoremediation, 33(1), 3-6. https://doi.org/10.1080/03004270585200021

Dimbisso, M.A. (2009). Parental school involvement and students' academic performance. Journal of Social Psychology, 75, 176-189.

Jaiswal, S. K. (2017). Role Of Parental Involvement And Some Strategies That Promote $\begin{array}{lllll}\text { Parental Involvement (Vol. 5). Retrieved } & \text { from }\end{array}$ http://www.jiarm.com/March2017/paper30242.pdf

Kilonzo, P.M. (2017). Impact of parenting style on personality dimensions of adolescent in public secondary schools: A case of Mombasa County, Kenya. International Journal of Education and Research, 5 (7), 263-276.

Stringer, R. W., \& Heath, N. (2008). Academic self-perception and its relationship to academic performance. Canadian Journal of Education, 31(2), 327-345.

Uchendu, V. C. (2007). Ezi Na Ulo: The extended family in Igbo civilization. Dialectical Anthropology, 31(1-3), 167-219. https://doi.org/10.1007/s10624-007-9019-4 